\title{
Regucalcin is broadly expressed in male reproductive tissues and is a new androgen-target gene in mammalian testis
}

\author{
S S Laurentino, S Correia, J E Cavaco, P F Oliveira, L Rato, M Sousa ${ }^{1,2}$, A Barros ${ }^{2,3}$ and S Socorro \\ CICS-UBI Health Sciences Research Center, University of Beira Interior, Avenida Infante D. Henrique, 6200-506 \\ Covilhã, Portugal, ${ }^{1}$ Laboratory of Cell Biology, Department of Microscopy, Institute of Biomedical Sciences Abel \\ Salazar (ICBAS), UMIB, University of Porto, Largo Prof. Abel Salazar 2, 4099-003 Porto, Portugal, ${ }^{2}$ Centre for \\ Reproductive Genetics Alberto Barros, Avenida do Bessa, 240, $1^{\circ}$ Dto Frente 4100-009 Porto, Portugal and \\ ${ }^{3}$ Department of Genetics, Faculty of Medicine, University of Porto, Alameda Prof. Hernâni Monteiro 4200 - 319 Porto, \\ Portugal
}

Correspondence should be addressed to S Socorro; Email: ssocorro@fcsaude.ubi.pt

S S Laurentino and S Correia contributed equally to this work

\begin{abstract}
Regucalcin (RGN) is a calcium $\left(\mathrm{Ca}^{2+}\right)$-binding protein which regulates intracellular $\mathrm{Ca}^{2+}$ homeostasis by modulating the activity of enzymes regulating $\mathrm{Ca}^{2+}$ concentration and enhancing $\mathrm{Ca}^{2+}$-pumping activity. Several studies have described the pivotal role of proper $\mathrm{Ca}^{2+}$ homeostasis regulation to spermatogenesis and male fertility. Recently, $R G N$ was identified as a sex steroid-regulated gene in prostate and breast; however, a possible role of RGN in spermatogenesis has not been examined. In this study, the expression and localization of RGN in rat and human testis, and other rat reproductive tissues was analyzed. Moreover, we studied whether RGN protein was present in seminiferous tubule fluid (STF). Finally, we examined the effect of $5 \alpha$-dihydrotestosterone (DHT) on the expression of Rgn mRNA in rat seminiferous tubules (SeT) cultured ex vivo. The results presented in this study show that RGN is expressed in Leydig and Sertoli cells, as well as in all types of germ cells of both rat and human testis. RGN is also expressed in rat prostate, epididymis, and seminal vesicles. Moreover, RGN protein is present in rat STF. The results also demonstrate that Rgn expression is age dependent in rat testis, and is upregulated by the non-aromatizable androgen DHT in rat SeT cultured ex vivo. Taken together, these findings indicate that Rgn is a novel androgen-target gene in rat testis and that it may have a role in male reproductive function, particularly in the control of spermatogenesis.

Reproduction (2011) 142 447-456
\end{abstract}

\section{Introduction}

Regucalcin (RGN) was first identified in the late 1970s by the Yamaguchi group in Japan as a calcium $\left(\mathrm{Ca}^{2+}\right)$ binding protein that does not contain EF-hand motif (Yamaguchi \& Yamamoto 1978). Independently, another research group identified and named it senescence marker protein 30, based on its characteristic downregulated expression with aging in rat liver (Fujita et al. 1992). RGN plays an important role in intracellular $\mathrm{Ca}^{2+}$ homeostasis by modulating the activity of enzymes regulating $\mathrm{Ca}^{2+}$ concentration, and enhancing $\mathrm{Ca}^{2+}$ pumping activity through the plasma membrane, endoplasmic reticulum and mitochondria of several cell types (Yamaguchi 2005). In turn, Rgn expression is upregulated by increased $\mathrm{Ca}^{2+}$ concentration in liver and kidney cells (Shimokawa \& Yamaguchi 1992, 1993, Yamaguchi \& Kurota 1995).

Although there are no studies characterizing expression of RGN in testis, several evidences have highlighted the importance of $\mathrm{Ca}^{2+}$ to spermatogenesis. Calcium is essential for the maintenance of Sertoli cell (SC) tight junctions forming the blood-testis barrier (Grima et al. 1998) and modulates the activity of enzymes interfering in SC architecture (Franchi \& Camatini 1985). The tight regulation of $\mathrm{Ca}^{2+}$ influx and outflux maintaining intracellular $\mathrm{Ca}^{2+}$ homeostasis also seems to be essential for Leydig cells (LC) steroidogenesis, for example by controlling the expression of STAR protein (Manna et al. 1999, Pandey et al. 2010). Moreover, it has been shown that administration of $\mathrm{Ca}^{2+}$ channel blockers has deleterious effects on mammalian spermatogenesis, being associated with reversible infertility (Juneja et al. 1990, Benoff et al. 1994, Almeida et al. 2000, Lee et al. 2006, 2011).

Recently, we have identified Rgn as a sex steroidregulated gene in rat reproductive organs such as breast and prostate (Maia et al. 2008, 2009). Also, we have shown that $5 \alpha$-dihydrotestosterone (DHT) treatment 
decreases $R G N$ expression in human prostate cancer cells (LnCaP; Maia et al. (2009)). However, the effects of sex steroids controlling RGN testicular expression are unknown.

The first aim of the present work was to study the expression and cellular localization of RGN in rat and human testis and other male reproductive tissues, such as prostate, epididymis, and seminal vesicles. RGN has been shown to be secreted to biological fluids, namely saliva (Carolan et al. 2009) and plasma (Isogai et al. 1994a, 1994b, Lv et al. 2007, 2008). Thus, secondly, we investigated whether $\mathrm{RGN}$ is present in seminiferous tubule fluid (STF). Our third aim was to determine the effect of DHT on Rgn expression in rat seminiferous tubules (SeT) cultured ex vivo.

\section{Results}

\section{RGN expression and localization in rat and human cell types of the testis}

RGN mRNA and protein expression was analyzed in rat and human whole testis and isolated SC by RT-PCR, in situ hybridization (ISH), western blot (WB), immunohistochemistry (IHC), and/or immunocytochemistry (ICC).

Analysis by RT-PCR demonstrated RGN mRNA expression in rat and human testis (Fig. 1A). Through real-time quantitative PCR (qPCR) analysis at different postnatal ages it was shown that Rgn mRNA expression in rat testis reaches a maximum at 120 days, and decreases during aging process (Fig. 1C).

The localization of Rgn mRNA in rat testis was assessed using a specific digoxigenin-labeled probe (Fig. 1D). We were able to localize Rgn hybridization signal in SC and several germ cells, namely spermatogonia (SG), spermatocytes (ST), and round spermatids (RS). Specificity of ISH staining was evaluated by hybridization with sense probe, which resulted in absence of signal (Fig. 1D insert).

In rat testis RGN protein was localized to LC and SC and also in a variety of germ cells, more specifically SG, ST, RS, elongating spermatids (ES), and spermatozoa (Sz; Fig. 2A and C). IHC in human testicular tissue showed a similar expression pattern for RGN, as observed by the staining of the same cell types as in rat testis (Fig. 2B and D). Although cell localization was essentially cytoplasmic, some nuclear staining is visible particularly in rat sections (Fig. $2 \mathrm{~A}$ and $\mathrm{C}$ ). Specificity of the IHC staining was assessed by omission of primary antibody, resulting in complete absence of immunological staining (inserts in corresponding panels, Fig. 2).

The expression of RGN mRNA and protein in SC was confirmed using rat and human primary SC cultures. PCR amplification of SC-specific markers vimentin (Vim) and anti-Müllerian hormone $(A m h ;$ Fig. $1 \mathrm{~A})$, and ICC detection of VIM (Fig. 2G and $\mathrm{H}$ ) were used to confirm the isolation of SC. After $96 \mathrm{~h}$ of culture contaminant cells
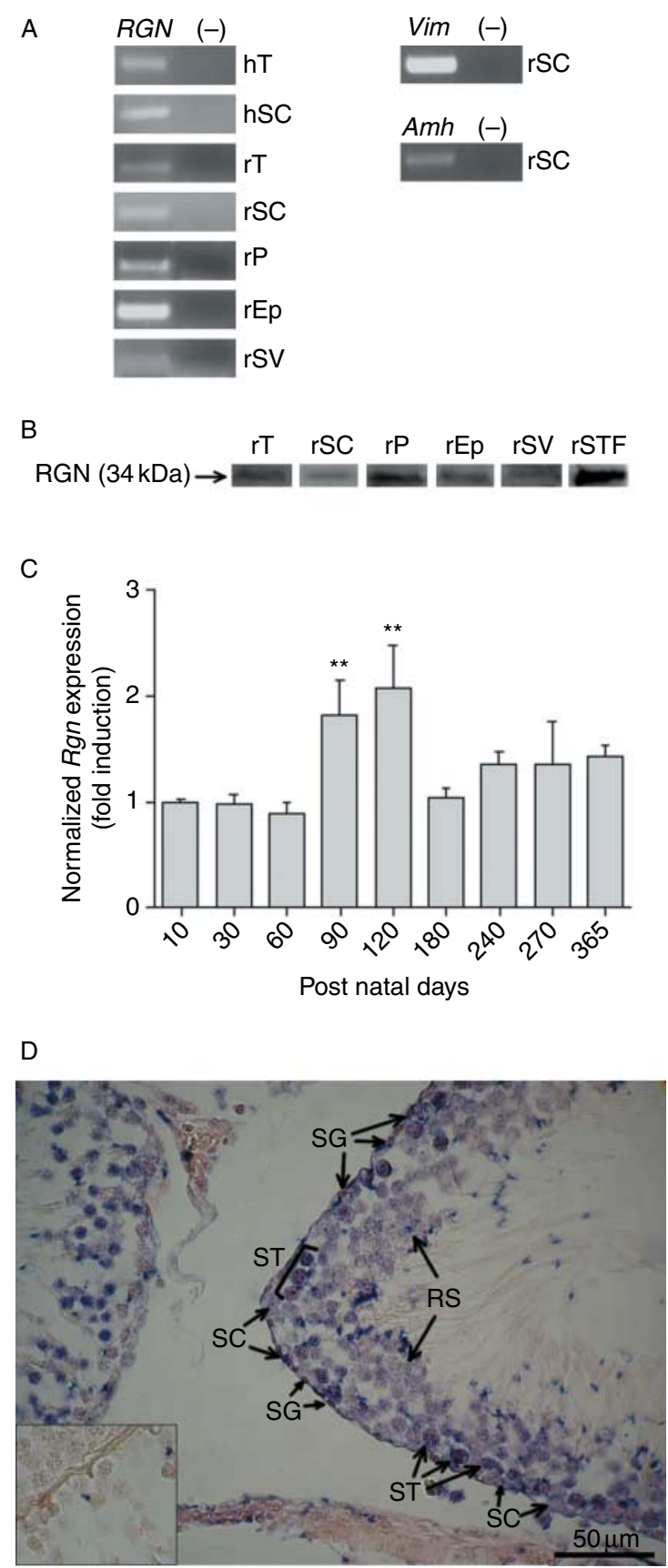

Figure 1 Expression of regucalcin (RGN) in reproductive tract tissues and seminiferous tubule fluid (STF). (A) RT-PCR of RGN, Sertoli cells (SC)-specific markers vimentin (Vim), and anti-Müllerian hormone $(A m h) .(-)$, Negative control (no cDNA template). (B) Western blot detection of RGN in protein extracts. $\mathrm{hT}$, human testis; $\mathrm{rT}$, rat testis; $\mathrm{hSC}$, human Sertoli cells; rSC, rat Sertoli cells; rP, rat prostate; rEp, rat epididymis; rSV, rat seminal vesicles; rSTF, rat seminiferous tubule fluid. (C) Expression of Rgn in rat testis at different postnatal ages, determined by quantitative PCR, normalized with cyclophilin A and $\beta 2$-microglobulin as internal reference genes. $n \geq 5$ in each group. ${ }^{* *} P<0.005$ relative to ten postnatal days. Error bars represent S.E.M. (D) Localization of Rgn mRNA transcript in adult rat testis by in situ hybridization using a digoxigenin-labeled antisense probe. Insert - hybridization with sense probe resulting in no staining. SC, Sertoli cell; SG, spermatogonia; ST, spermatocyte; RS, round spermatid. Magnification indicated as scale bar. 

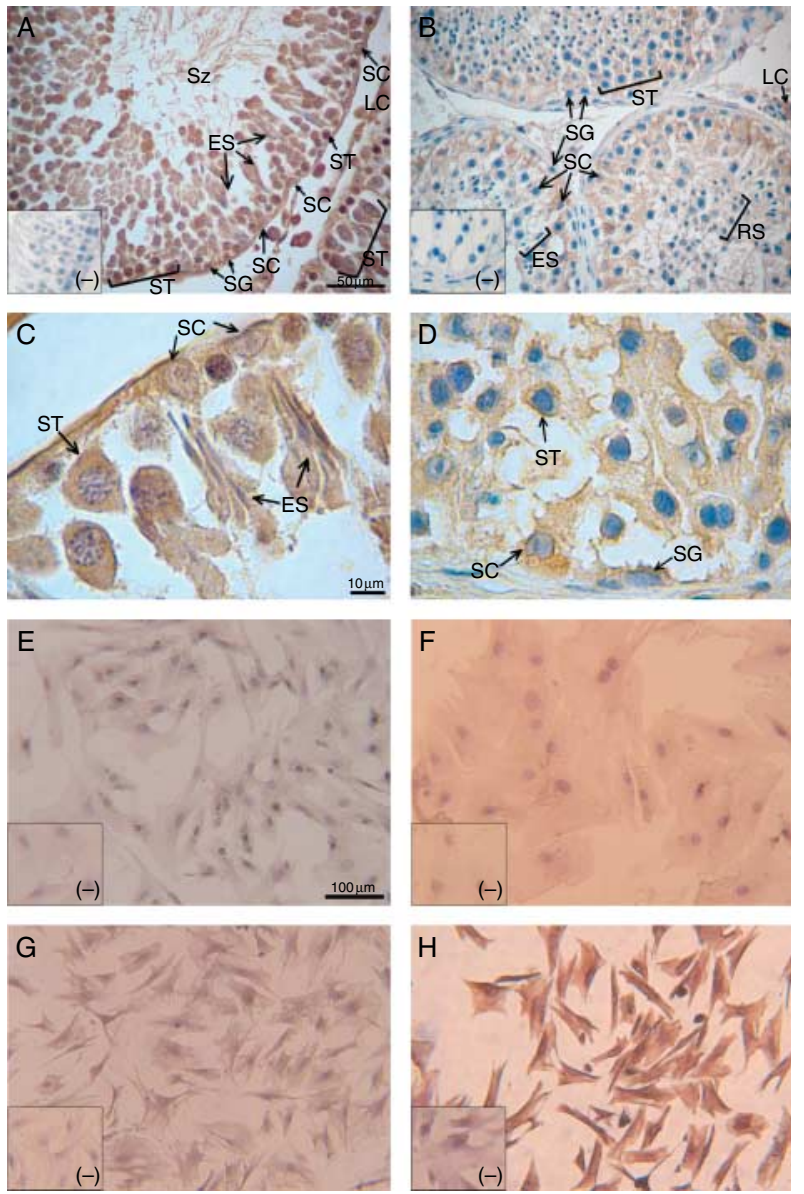

Figure 2 Immunochemical localization of regucalcin in testis paraffinsections and Sertoli cell (SC) cultures. (A and C) Rat testis, (B and D) human testis, (E) rat SC, and (F) human SC. Purity of the rat and human SC cultures was assessed by staining with anti-vimentin antibody ( $\mathrm{G}$ and $\mathrm{H}$ respectively). (-), Negative control obtained by omission of the primary antibody (inserts in corresponding panels). SC, Sertoli cell; LC, Leydig cell; SG, spermatogonia; ST, spermatocyte; RS, round spermatid; $\mathrm{ES}$, elongated spermatid; Sz, spermatozoa. Magnification indicated as scale bar (B similar to $A$; $D$ similar to $C ; F, G$, and $H$ similar to $E$ ).

were fewer than $5 \%$ for both cultures. By RT-PCR, RGN mRNA expression was detected in both rat and human SC (Fig. 1A). These cells also expressed RGN protein, which was detected mainly to the cytoplasm (Fig. 2E and F). Specificity of the immunostaining was assessed by the omission of the primary antibody, which resulted in complete absence of immunological staining (inserts in corresponding panels, Fig. 2). The presence of RGN in rat SC was further confirmed by WB analysis (Fig. 1B).

\section{RGN expression in rat reproductive tissues and STF}

The expression of RGN in other rat reproductive tissues besides testis was investigated. We detected Rgn mRNA expression in rat prostate, epididymis, and seminal vesicles (Fig. 1A). Subsequently, we confirmed the expression of RGN protein in these tissues by detecting an immunoreactive band of expected size in WB (Fig. 1B). Moreover, we detected the same immunoreactive band in rat STF (Fig. 1B).

The cellular localization of RGN in rat prostate, epididymis, and seminal vesicles was determined by IHC. In all three tissues RGN was localized mainly in the epithelial cells (Fig. 3A-C); in epididymis it was also localized to smooth muscle cells and connective tissue (Fig. 3B). Specificity of staining was assessed by omission of the primary antibody, which resulted in complete absence of staining (inserts in corresponding panels, Fig. 3).

\section{$D H T$ regulation of $\mathrm{Rgn}$ expression in rat $\mathrm{SeT}$}

The effect of DHT $\left(10^{-7} \mathrm{M}\right)$ on the expression of $R g n$ mRNA in cultured rat SeT was evaluated by qPCR. First, a time-course experiment was performed showing that DHT induced a sharp increase in the expression levels of $R g n$ at $24 \mathrm{~h}(4.37 \pm 0.64 ; P<0.001)$ compared with control $(1.00 \pm 0.26)$, while at all other experimental times Rgn expression levels remained similar to control group (Fig. 4A). The $24 \mathrm{~h}$ experimental time was therefore selected to explore the mechanisms involved in DHT regulation of Rgn expression by incubating rat SeT with $10^{-7} \mathrm{M} \mathrm{DHT}$, and with antiandrogen flutamide (Flu) and protein synthesis inhibitor cycloheximide (CHX), alone or in presence of DHT (Fig. 4B). Treatment with DHT produced an increase in $\operatorname{Rgn} \mathrm{mRNA}$ expression $(2.20 \pm 0.27 ; P<0.01)$ compared with the control $(1.00 \pm 0.08)$. Administration of Flu neutralized the hormone's effect $(1.04 \pm 0.06$ vs $1.00 \pm 0.08$ control), while incubation with $\mathrm{CHX}(2.34 \pm 0.15$ vs $1.00 \pm 0.08$ control; $P<0.001$ ) did not change the upregulating effect of DHT on Rgn expression. Incubation with Flu or CHX alone had no significant effect on the expression of Rgn.

\section{Rgn expression is upregulated in rat SeT cultured in presence of survival factors}

Rat SeT were cultured in a hormone-free medium with or without survival factors, and the expression of Rgn quantified by qPCR (Fig. 4C). Under survival-promoting conditions there was an upregulation of Rgn expression $(2.23 \pm 0.22$ vs $1.00 \pm 0.23$ without survival factors; $P<0.005)$.

\section{Discussion}

Although several studies have highlighted the importance of $\mathrm{Ca}^{2+}$ homeostasis and signaling for normal spermatogenic process, a possible role of RGN in testicular physiology had not been explored. In this study, we report the expression and localization of RGN in rat and human testis and the effect of DHT on its expression.

Expression of RGN mRNA was detected in rat and human testicular tissue (Fig. 1A) and transcripts were 

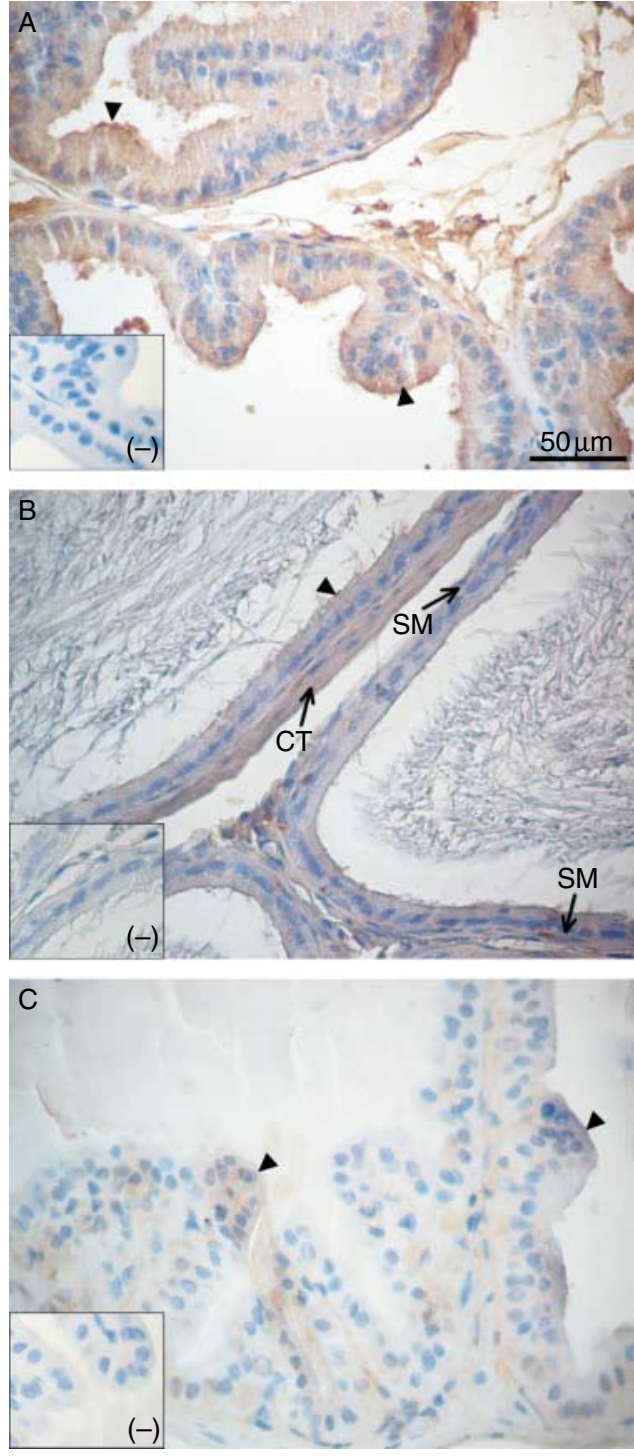

Figure 3 Immunohistochemical localization of regucalcin in rat prostate (A), epididymis (B), and seminal vesicles (C). (-), Negative control obtained by omission of the primary antibody (inserts in corresponding panels). Arrowhead, epithelium; CT, connective tissue; SM, smooth muscle cells. Magnification indicated as scale bar (similar in all panels).

localized both to somatic and germ cells in adult rat testis (Fig. 1D). A developmentally regulated expression pattern, where a peak is reached after which levels decrease with aging, has been described for Rgn in rat kidney and liver tissues. In rat kidney the expression of Rgn mRNA starts to increase at 21 postnatal days and reaches a peak at 35 days, levels are maintained high until 3 months when it starts to decrease, returning to the low levels observed before 21 days (Fujita et al. 1996). In a comparable manner, Rgn expression in liver increases until 10-day-old, reaching a plateau that is maintained until 6.5 months, decreasing in senescent rats (Fujita et al. 1996). The authors hypothesized that the age-dependent increase of Rgn expression in liver and kidney was coupled with periods of maturation and differentiation for both tissues and suggested it as a senescence marker (Fujita et al. 1996). Developmental analysis shows that in rat testis the characteristic downregulation of Rgn expression during aging is also observed. The expression of Rgn mRNA increases until it reaches a maximum at 120 days of age, a period which corresponds to rat adulthood, decreasing afterwards with rat aging (Fig. 1C).

The results presented in this study demonstrate that RGN protein is broadly expressed in rat (Fig. 2A) and human (Fig. 2B) testis, being localized to all cell types of the SeT epithelium, somatic as well as germ cells. Relative intensity of RGN staining appears to be weaker in human sections, a pattern we have consistently observed when analyzing the localization of other proteins in human and rat testis sections (data not shown). We think that the use of different fixation protocols may be causing this histological artifact. RGN immunostaining is visible in cytoplasm as well as in nucleus, which is in accordance with reports showing that RGN is able to translocate to the nucleus regulating DNA synthesis and gene expression (Inagaki \& Yamaguchi 2001, Tsurusaki \& Yamaguchi 2004, Maia et al. 2009). This is the first report describing RGN expression and localization in testis of any vertebrate.

Tight control of intracellular $\mathrm{Ca}^{2+}$ homeostasis has been shown to be of uttermost importance to LC steroidogenesis (Manna et al. 1999, Pandey et al. 2010) and maintenance of SC function (Franchi \& Camatini 1985, Grima et al. 1998, Gorczynska-Fjalling 2004). The deleterious effects of $\mathrm{Ca}^{2+}$ channel blockers on male fertility emphasize even more the importance of tight $\mathrm{Ca}^{2+}$ regulation to spermatogenesis (Juneja et al. 1990, Benoff et al. 1994, Almeida et al. 2000, Lee et al. 2006, 2011). The common cellular localization pattern observed in rat and human testis, together with the wide cellular distribution of RGN indicate a relevant role in testicular physiology suggesting that RGN may play a role in spermatogenesis as $\mathrm{a} \mathrm{Ca}^{2+}$ homeostasis regulator in both somatic and germ cells.

Knowing that RGN was identified as a secreted protein in a pea aphid saliva (Carolan et al. 2009), and murine (Lv et al. 2007, 2008), rat (Isogai et al. 1994a, 1994b), and human plasma (Lv et al. 2008) we decided to investigate its presence in STF, which could be confirmed by WB analysis (Fig. 1B). The STF is produced essentially due to the secretory activity of SC (Fisher 2002), which we demonstrated, by several approaches, to express RGN. Therefore, it is highly expected that RGN present in STF may be a secretion product of SC. Exogenous RGN has been shown to translocate to the nucleus being capable of altering gene expression and modulating enzyme activity in osteoblasts (Otomo \& Yamaguchi 2006) and liver cells (Omura \& Yamaguchi 1999). Nevertheless, to 


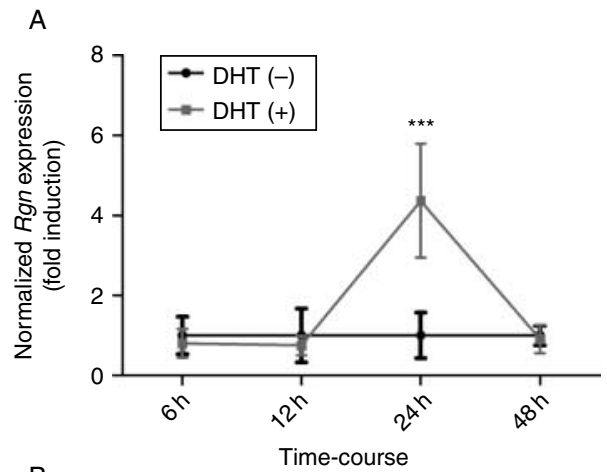

$$
\text { B }
$$

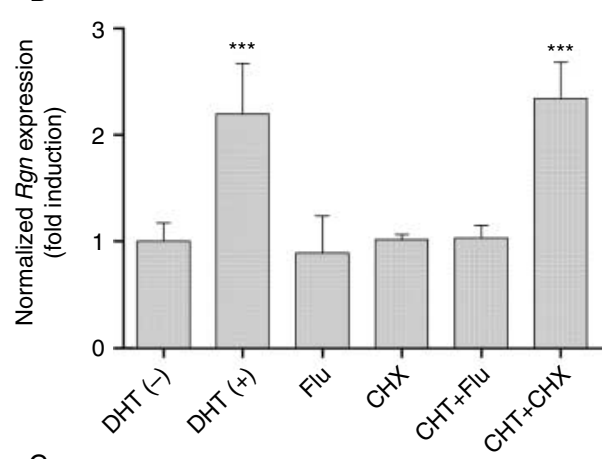

$$
\text { C }
$$

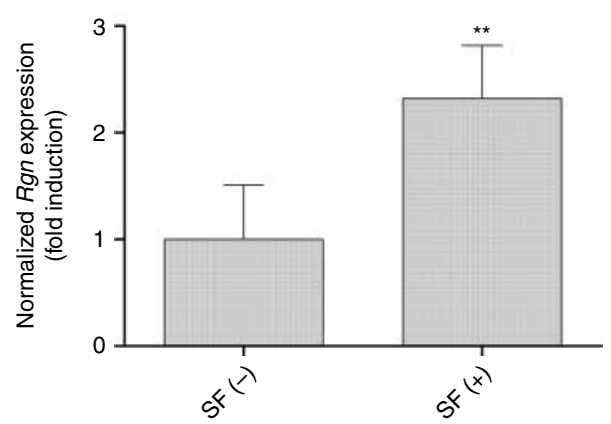

Figure 4 Effect of DHT and survival factors on regucalcin (Rgn) expression in rat seminiferous tubules (SeT) cultured ex vivo determined by quantitative PCR. Rgn expression was normalized with $\beta$-actin and Gapdh as internal reference genes. $n=5$ in each experimental condition. Error bars represent S.E.M. (A) Time-course experiment in which rat SeT were cultured in the absence [DHT $(-)$ ] or presence of $10^{-7} \mathrm{MDHT}[\mathrm{DHT}(+)]$ for $6,12,24$, or $48 \mathrm{~h}$. (B) Rat SeT cultured for $24 \mathrm{~h}$ with $10^{-7} \mathrm{M} \mathrm{DHT}, 10^{-7} \mathrm{M}$ flutamide (Flu), $10 \mu \mathrm{g} / \mathrm{ml}$ cycloheximide $(\mathrm{CHX}), 10^{-7} \mathrm{M}$ DHT plus $10^{-7} \mathrm{M} \mathrm{Flu}$, and $10^{-7} \mathrm{M}$ DHT plus $10 \mu \mathrm{g} / \mathrm{ml} \mathrm{CHX.}{ }^{* *} P<0.005$ and ${ }^{* * *} P<0.001$ compared with DHT $(-)$. (C) Rat SeT cultured for $24 \mathrm{~h}$ in the absence [SF $(-)]$ or presence of $[\mathrm{SF}(+)]$ survival factors ${ }^{* *} P<0.005$.

this point, the role of SeT secreted RGN remains to be determined.

In addition to testis we also analyzed the expression and localization of RGN in other rat reproductive tissues: prostate, epididymis, and seminal vesicles (Fig. 3). This is the first time RGN expression and immunolocalization have been reported in rat epididymis and seminal vesicles. In seminal vesicles, RGN immunostaining is confined to epithelial cells, while in epididymis it is also present in connective tissue and smooth muscle cells.
In rat prostate RGN protein was detected in epithelial cells, which is in accordance with published results in rat and human prostatic tissue (Maia et al. 2008, 2009). RGN has been proposed to have a physiological function in prostate, as its expression is downregulated in prostate cancer tissues, and RGN immunoreactivity correlates with the grade of adenocarcinoma cellular differentiation (Maia et al. 2009). However, further studies are required to detail $R G N$ function in these tissues.

Administration of $17 \beta$-estradiol $\left(E_{2}\right)$ to rats causes an increase in the expression of Rgn mRNA in the liver (Yamaguchi \& Oishi 1995). The same effect is observed in cultured rat hepatoma cells (Nakajima et al. 1999). Also, in osteoblastic cells, incubation with $E_{2}$ causes an upregulation of Rgn expression, while treatment with 1,25-dihydroxyvitamin $\mathrm{D}_{3}$ causes downregulation of Rgn expression (Yamaguchi et al. 2008). Contrarily, administration of $E_{2}$ to rats decreases the expression of Rgn in renal cortex (Kurota \& Yamaguchi 1996). The hormonal regulation of $R g n$ expression has also been described in sex hormone target organs. Our group has described the downregulation of Rgn expression in rat prostate and mammary gland by $\mathrm{E}_{2}$ (Maia et al. 2008). Moreover, $R G N$ is underexpressed in breast and prostate cancer cases and $E_{2}$ upregulated while DHT downregulated $R G N$ mRNA expression in MCF-7 and LNCaP cell lines, respectively (Maia et al. 2009). DHT, a nonaromatizable androgen, has been shown to stimulate spermatogenesis in a similar way to testosterone (Singh et al. 1995, Meachem et al. 2007, O'Shaughnessy et al. 2010), therefore it was used to analyze the effect of androgens on Rgn expression in rat SeT cultured ex vivo. qPCR analysis showed that DHT upregulates Rgn mRNA expression in rat cultured SeT at $24 \mathrm{~h}$ of exposure (Fig. 4A). DHT upregulation of Rgn expression is completely reversed by incubation with antiandrogen Flu, but not with $\mathrm{CHX}$, an inhibitor of protein synthesis (Fig. 4B). These data suggest that the involvement of a classical genomic mechanism of gene expression regulation through androgen receptor, which seems not to depend on de novo protein synthesis. In silico analysis of the $R G N$ promoter region has in fact enabled the identification of androgen response elements upstream from transcription initiation site at positions -906, -915, -4126, and -5822 bp (Maia et al. 2009). Nevertheless, androgens are known to increase intracellular $\left[\mathrm{Ca}^{2+}\right]$ in a wide array of cells, namely SC (Gorczynska \& Handelsman 1995), human prostatic stromal cells (Oliver et al. 2010), rat thoracic aorta (Montano et al. 2008), and human lymphocytes (Popova et al. 2007). It is also known that Rgn expression is upregulated by increased $\left[\mathrm{Ca}^{2+}\right]$ (Shimokawa \& Yamaguchi 1992, 1993). Therefore, we do not exclude that the DHT-induced rise in Rgn expression may be partly due to a secondary increase in intracellular $\mathrm{Ca}^{2+}$.

Maintenance of spermatogenic epithelium homeostasis requires a fine-tuning between germ cell 
proliferation and death. Apoptosis is an essential mechanism that enables the elimination of abnormal and exceeding germ cells and therefore its regulation is vital for normal spermatogenesis (Print \& Loveland 2000). Up to $75 \%$ of germ cells undergo death by apoptosis in testis during the pubertal maturation process (Giampietri et al. 2005). On the other hand, androgens are known to inhibit apoptosis of male germ cells (Erkkila et al. 1997, Pentikainen et al. 2000) and testosterone withdrawal stimulates their apoptosis (Nandi et al. 1999, Tesarik et al. 2002). Germ cell apoptosis induced by androgen deprivation seems to be associated with caspases activation (Vera et al. 2006, Johnson et al. 2008). The role of RGN controlling apoptotic cell death has been established. RGN overexpression inhibits apoptosis induced by several factors, namely tumor necrosis factor- $\alpha$ and thapsigargin, dibucaine, and Bay $\mathrm{K}$ (Izumi \& Yamaguchi 2004a, 2004b), and it was suggested that it may regulate AKT activity (Matsuyama et al. 2004). In addition, hepatocytes of RGN knockout mice are more susceptible to apoptotic cell death than their wild-type counterparts (Ishigami et al. 2002). We hypothesize that the upregulated expression of $R g n$ in SeT in response to DHT might be a mechanism by which androgens regulate apoptosis in testis. This is further supported by the observation that culture of SeT under hormone-free conditions although in presence of survival factors induces an upregulation of $R g n$ expression similar to the one caused by treatment with DHT (Fig. 4C).

In conclusion, we demonstrate that RGN is expressed in rat and human testis and other tissues of male reproductive tract, namely prostate, epididymis, and seminal vesicles. In addition, the presence of RGN in STF was identified. Our results also indicate Rgn as a novel androgen-target gene in rat testis that may have an important role in the control of spermatogenesis. This opens new lines of research to explore the role of RGN and $\mathrm{Ca}^{2+}$ homeostasis in male spermatogenic process and fertility.

\section{Materials and Methods}

\section{Animals and tissues}

Wistar male rats (Rattus norvegicus) were obtained from Charles River (Barcelona, Spain) and housed under a $12 \mathrm{~h}$ light:12 $\mathrm{h}$ darkness cycle, with food and water available ad libitum during the course of all experiments. Housing, maintenance and handling of animals was in compliance with the NIH guidelines and the rules for the care and handling of laboratory animals (Directive 86/609/EEC). All rats were killed under anesthesia (Clorketam1000, Vetoquinol, Lure, France).

Human testicular samples with conserved spermatogenesis were obtained by testicular sperm extraction from men undergoing treatment testicular biopsy due to obstructive azoospermia (aged 35-38, with normal karyotypes). Samples were obtained under informed consent according to the local ethics committee guidelines, and treated as described previously (Sousa et al. 2002a).

\section{Reagents}

All chemical reagents were purchased from Sigma-Aldrich and all antibodies were obtained from AbCam (Cambridge, UK) unless stated otherwise.

\section{Primary SC culture}

Testes were removed from 22-day-old rats and washed in ice-cold Hanks balanced salt solution without $\mathrm{Ca}^{2+}$ and $\mathrm{Mg}^{2+}$ (HBSSf). Testes were decapsulated and washed in HBSSf. Rat SC were then isolated by a method adapted by Oliveira et al. (2009a). Briefly, decapsulated testicular tissue was placed in a glycine-containing medium (HBSSf, $1 \mathrm{M}$ glycine (Merck), $0.005 \%(\mathrm{w} / \mathrm{v})$ DNase, $2 \mathrm{mM}$ EDTA and $0.002 \%(\mathrm{w} / \mathrm{v})$ soybean trypsin inhibitor, $\mathrm{pH}$ 7.2) for $10 \mathrm{~min}$ at room temperature (RT) to remove peritubular cells. The dispersed tubules were forced through a large-bore Pasteur pipette and digested with $0.015 \%$ $(\mathrm{w} / \mathrm{v})$ type I collagenase and $0.005 \%(\mathrm{w} / \mathrm{v})$ DNase in HBSSf for $20 \mathrm{~min}$ at RT. The SC suspension was collected by centrifugation at $300 \boldsymbol{g}$ for $3 \mathrm{~min}$, washed three times in HBSSf and resuspended in SC culture medium (1:1 mix of Ham's F12 and DMEM supplemented with $15 \mathrm{mM}$ HEPES, $50 \mathrm{IU} / \mathrm{ml}$ penicillin, $50 \mathrm{mg} / \mathrm{ml}$ streptomycin sulfate, $0.5 \mathrm{mg} / \mathrm{ml}$ Fungizone, $50 \mu \mathrm{g} / \mathrm{ml}$ gentamicin, and $5 \%(\mathrm{v} / \mathrm{v})$ heat-inactivated FBS (Biochrom, Berlin, Germany)). The cell suspension was forced through a 20G needle, plated in culture flasks (Cell+; Sarstedt, Nümbrecht, Germany) at a concentration of 5000 clusters $/ \mathrm{ml}$ and incubated at $37^{\circ} \mathrm{C}$ in an atmosphere of $5 \% \mathrm{CO}_{2}: 95 \% \mathrm{O}_{2}$.

To obtain a culture of human SC, testicular biopsies were treated according to a method described by Sousa et al. (2002b). Isolation of SC was made by a method described elsewhere (Oliveira et al. 2009b) with some modifications. The tubules were centrifuged at $500 \mathrm{~g}$ for $5 \mathrm{~min}$ and washed in HBSSf followed by another centrifugation. The pellet was redissolved in SC culture medium with a composition similar to the one used for rat SC culture except for the addition of $10 \%$ $(\mathrm{v} / \mathrm{v})$ heat-inactivated FBS, and cultured in a similar way.

\section{STF collection}

STF was collected from 90-day-old rats following a method described by Turner et al. (1984) with some modifications. Briefly, testes were removed and trimmed free of fat and connective tissue. A small incision was made at the caudal end of each testis, which was placed inside a syringe barrel within a centrifuge tube. The apparatus was centrifuged at $54 \boldsymbol{g}$ for $15 \mathrm{~min}$ at $0^{\circ} \mathrm{C}$ to remove interstitial fluid. The testis was removed from the barrel, the tunica was cut and peeled back, and tubules were washed four times in saline to remove remaining interstitial fluid and blotted onto gauze. Tubules were extruded through the hub of a syringe into a centrifuge tube and centrifuged for $30 \mathrm{~min}$ at $0{ }^{\circ} \mathrm{C}$. Supernatant containing STF was collected into a fresh tube. 


\section{Ex vivo culture of rat SeT}

Rat SeT were used for culture instead of individual cell types, since this model has been shown to be suitable to mimic the testicular cellular environment ex vivo by several groups (Gilleron et al. 2009, Kaisman-Elbaz et al. 2009, GeoffroySiraudin et al. 2010). Testes (90-day-old rats) were removed, trimmed free of fat, washed in cold PBS and placed in DMEMF12 culture medium at $32{ }^{\circ} \mathrm{C}$. Tunica was cut and peeled back to expose tubules. Ten SeT fragments of about $1 \mathrm{~cm}$ and $2 \mathrm{ml}$ of culture medium were used per well (Nunclon D 12 well multidishes; Nunc, Roskilde, Denmark). Experimental groups according to the medium composition were $(n=5$ in each group): control, DHT $\left(10^{-7} \mathrm{M}\right)$, Flu $\left(10^{-7} \mathrm{M}\right)$, DHT+Flu $\left(10^{-7} \mathrm{M}\right.$ DHT and $10^{-7} \mathrm{M}$ Flu $), \mathrm{CHX}(10 \mu \mathrm{g} / \mathrm{ml})$, and DHT + $\mathrm{CHX}\left(10^{-7} \mathrm{M} \mathrm{DHT}\right.$ and $10 \mu \mathrm{g} / \mathrm{ml}$ of $\left.\mathrm{CHX}\right)$. Control medium, to which DHT/Flu/CHX were added was DMEM-F12 supplemented with $20 \mathrm{mg} / \mathrm{l}$ gentamicin sulfate, $0.1 \mathrm{mM}$ 3-isobutyl-1methylxanthine, and $1 \mathrm{mg} / \mathrm{I} \mathrm{BSA}$. In groups with DHT plus Flu/ $\mathrm{CHX}$, the hormone was added $30 \mathrm{~min}$ after Flu/CHX. Tubules were incubated for $6,12,24$, and $48 \mathrm{~h}$ in time-course experiments, and for $24 \mathrm{~h}$ in experiments with Flu and $\mathrm{CHX}$. Tubules were also cultured in control medium supplemented with survival factors $(10 \%(\mathrm{v} / \mathrm{v})$ heat-inactivated FBS, $1 \mathrm{mM} \mathrm{Na}$ pyruvate, $4 \mathrm{mM}$ glutamine, $100 \mathrm{ng} / \mathrm{ml}$ vitamin A, $200 \mathrm{ng} / \mathrm{ml}$ vitamin E, $50 \mathrm{ng} / \mathrm{ml}$ vitamin C, and $12 \mu \mathrm{g} / \mathrm{ml}$ insulin) for $24 \mathrm{~h}$. SeT remained viable during the course of the experiment as assessed by morphological analysis of hematoxylin-and-eosinstained tissue sections. At the end of each experiment tubules were recovered from medium, snap-frozen in liquid nitrogen and stored at $-80{ }^{\circ} \mathrm{C}$ until RNA isolation.

\section{RNA isolation and CDNA synthesis}

RNA was isolated from rat and human testis, rat SeT, rat prostate, rat epididymis, rat seminal vesicles, and rat and human SC with TRI reagent according to the manufacturer's instructions. RNA concentration was measured in a spectrophotometer (NanoPhotometer, Implen, Munich, Germany) and integrity was assessed by agarose gel electrophoresis. Total RNAs were decontaminated from genomic DNA by digestion with DNase I (amplification grade) according to the manufacturer's instructions. cDNA was synthesized in a final volume of $20 \mu \mathrm{l}$ using $160 \mathrm{IU}$ M-MLV reverse transcriptase (Promega), $0.5 \mu \mathrm{g}$ random primers (Invitrogen), 10 mM each dNTP (GE Healthcare, Buckinghamshire, UK) and $1 \mu \mathrm{g}$ each RNA sample according to the protocol supplied by the manufacturer. Synthesized cDNA was stored at $-20{ }^{\circ} \mathrm{C}$ until further use.

\section{RT-PCR}

For the amplification of human and rat $R G N$, rat Vim and rat Amh specific intron-spanning primer sets were designed (Table 1). cDNA $(1 \mu \mathrm{l})$ was amplified in a final volume of $25 \mu \mathrm{l}$ containing $1 \times$ DreamTaq buffer with $20 \mathrm{mM} \mathrm{MgCl}_{2}$ (Fermentas, Burlington, Ontario, Canada), 0.5 IU of DreamTaq DNA polymerase (Fermentas), $10 \mathrm{mM}$ each dNTP (GE Healthcare), and $0.2 \mu \mathrm{M}$ each primer (StabVida, Oeiras, Portugal). Every set of PCR included a no-template control.

\section{In situ hybridization}

Detection of Rgn mRNA in rat testis (90-day-old) 4\% PFA-fixed, paraffin-embeded sections was performed by hybridization with digoxigenin-labeled probes according to a protocol as described previously (Maia et al. 2008).

\section{Western blot}

Total protein was isolated from rat SC, testis, prostate, epididymis, and seminal vesicles using RIPA buffer supplemented with protease inhibitors (1 mM PMSF; $5 \mathrm{mM}$ EDTA; $1 \times$ protease inhibitor cocktail). Protein content in STF was concentrated by acetone precipitation. Protein pellet was

Table 1 PCR primer sequences, amplicon size, and cycling conditions.

\begin{tabular}{|c|c|c|c|}
\hline Gene and accession numbers & Primer sequences $\left(5^{\prime}-3^{\prime}\right)$ & Amplicon size (bp) & Annealing temperature $\left({ }^{\circ} \mathrm{C}\right)$ \\
\hline Rat vimentin & S: AGATCGATGTGGACGTTTCC & 198 & 50 \\
\hline NM_031140.1 & AS: TCCGGTATTCGTTTGACTCC & & \\
\hline Rat anti-Müllerian hormone & S: GGCTGTGTTACAGGCTGACA & 210 & 54 \\
\hline NM_012902.1 & AS: GACTCTTGGACAGCCTCCAG & & \\
\hline Human $R G N$ & S: GCCTGTCCTACTCCGTGGATGC & 143 & 55 \\
\hline NM_152869.2 & AS: GGCCАСССАGАGСТTССССТ & & \\
\hline Rat Rgn & S: TCAAAGACTGTCTGCCGATG & 93 & 56 \\
\hline NM_031546.1 & AS: GACTGTCGAAGTGCCACTGA & & \\
\hline Rat $\operatorname{Rgn}^{\mathrm{a}}$ & S: GGAGGAGGCATCAAAGTG & 155 & 60 \\
\hline NM_031546.1 & AS: CAATGGTGGCAACATAGC & & \\
\hline B-actin ${ }^{a}$ & S: ATGGTGGGTATGGGTCAG & 97 & 60 \\
\hline NM_031144.2 & AS: CAATGCCGTGTTCAATGG & & \\
\hline$G a \overline{p d} h^{\mathrm{a}}$ & S: GTTCAACGGCACAGTCAAG & 115 & 60 \\
\hline NM_017008.3 & AS: CTCAGCACCAGCATCACC & & \\
\hline Cyclophilin $\mathrm{A}^{\mathrm{a}}$ & S: CAAGACTGAGTGGCTGGATGG & 163 & 60 \\
\hline NM_017101.1 & AS: GCCCGCAAGTCAAAGAAATTAGAG & & \\
\hline B2-microglobulin ${ }^{a}$ & S: CCGTGATCTTTCTGGTGCTTGTC & 150 & 60 \\
\hline NM_012512.1 & AS: CTATCTGAGGTGGGTGGAACTGAG & & \\
\hline
\end{tabular}

S, sense primer; AS, antisense primer.

a Primer pairs used in quantitative PCR. 
dissolved in RIPA buffer with inhibitors. Protein concentration was determined by Bio-Rad protein assay.

Proteins $(100 \mu \mathrm{g})$ were mixed with sample buffer, denatured for $10 \mathrm{~min}$ at $100{ }^{\circ} \mathrm{C}$ and resolved by SDS-PAGE on $12.5 \%$ gels. Proteins were blotted onto PVDF membranes (GE Healthcare) by wet transfer using $10 \mathrm{mM}$ pH 11 CAPS with $20 \%(\mathrm{v} / \mathrm{v})$ methanol. Blotted membranes were blocked with Tris-buffered saline with $0.05 \%(\mathrm{v} / \mathrm{v})$ Tween-20 and 5\% (w/v) dry skimmed milk for $1 \mathrm{~h}$ at RT and then incubated overnight with primary monoclonal anti-RGN antibody (1:250; ab81721). Membranes were incubated with secondary antibody conjugated with alkaline phosphatase (1:15 000; anti-mouse IgG-AP, ab7069), developed for 5 min with ECF substrate (GE Healthcare) and scanned with Molecular Imager FX (Bio-Rad).

\section{Immunohistochemistry}

Sections $(5 \mu \mathrm{m})$ of rat (90-day-old) testis, prostate, epididymis, and seminal vesicles (4\% PFA-fixed) and human testis (10\% formalin-fixed) were deparaffinized in xylene and rehydrated in graded alcohols. Heat-induced antigen retrieval was performed in $10 \mathrm{mM}$ citric acid $\mathrm{pH} 6.0$ for $30 \mathrm{~min}$, at $80-85^{\circ} \mathrm{C}$. Endogenous peroxidase was blocked by incubating samples in $3 \%(\mathrm{v} / \mathrm{v}) \mathrm{H}_{2} \mathrm{O}_{2}$ (Panreac, Barcelona, Spain) for 10 min at RT and unspecific staining was blocked by incubation with 1:20 normal goat serum for $30 \mathrm{~min}$ at RT. Sections were incubated overnight at $4{ }^{\circ} \mathrm{C}$ with primary monoclonal anti-RGN antibody (ab81721) diluted 1:50 in PBS with $1 \%(w / v)$ BSA (PBA). Sections were then incubated with secondary goat anti-mouse biotinylated antibody (ab7067) diluted 1:200 in PBA for $1 \mathrm{~h}$ at RT, followed by incubation with ExtrAvidin Peroxidase diluted 1:20 in PBA. Antibody binding was detected using HRP substrate solution (Dako, Glostrup, Denmark). Sections were slightly counterstained with Harris' hematoxylin (Merck), dehydrated, cleared, and mounted. Specificity of the staining was assessed by the omission of primary antibody.

\section{Immunocytochemistry}

Human and rat cultured SC were washed with PBS and fixed with cold $4 \%$ PFA. Permeabilization was performed by incubation with $0.01 \%(\mathrm{w} / \mathrm{v})$ digitonin for $10 \mathrm{~min}$ at RT. Endogenous peroxidase was blocked by incubation with $0.1 \%(\mathrm{v} / \mathrm{v}) \mathrm{H}_{2} \mathrm{O}_{2}$ for $10 \mathrm{~min}$ at $\mathrm{RT}$ and unspecific staining was blocked with PBA for $30 \mathrm{~min}$ at RT. Cells were incubated overnight at $4{ }^{\circ} \mathrm{C}$ with primary monoclonal anti-RGN antibody (1:50 in PBA, ab81721) or ready-to-use polyclonal anti-Vim antibody (V9 clone, Invitrogen). Cells were then incubated with secondary horse anti-mouse biotinylated antibody (BA-200; Vector Labs, Burlingame, CA, USA) diluted 1:400 in PBA for $1 \mathrm{~h}$ at RT, followed by incubation with ExtrAvidin Peroxidase diluted 1:20 in PBA. Antibody binding was detected using HRP substrate solution. After color development sections were slightly counterstained with Harris' hematoxylin. Specificity of the staining was assessed by omission of primary antibody.

\section{qPCR}

Quantification of Rgn expression in rat cultured SeT and rat testis at different postnatal ages (10, 30, 60, 90, 120, 180, 240, 270 , and 365 days, $n \geq 5$ in each group) was performed by qPCR. An intron-spanning primer set was designed for the quantification of rat Rgn expression (Table 1). In addition two internal reference genes ( $\beta$-actin and Gapdh for cultured SeT; $\beta 2$-microglobulin and cyclophilin A for rat testis at different postnatal ages) were selected from a panel for the normalization of the expression based on their stability in the experimental conditions used according to two methods described elsewhere (Vandesompele et al. 2002, Andersen et al. 2004; data not shown). Reactions were carried out in an iQ5 system (Bio-Rad) and efficiency of the reactions was determined for all primer sets using serial dilutions of cDNA samples $(1: 1,1: 10$, and 1:100). Primer concentration and annealing temperature were optimized before the assay and specificity of the amplicons was determined by melting curve analysis. Reaction mixtures consisted of SYBR Green master mix (Bio-Rad), sense and antisense primers (500 nM for RGN and $200 \mathrm{nM}$ for all other primer pairs), and $1 \mu \mathrm{l}$ of cDNA in a final volume of $20 \mu \mathrm{l}$. Also, a no-template control was included for each reaction and all reactions were carried out in triplicate. Normalized expression values of Rgn were calculated according to a published mathematical model proposed by the Vandesompele group (Hellemans et al. 2007).

\section{Statistical analysis}

Statistical significance of differences in Rgn expression between groups was evaluated by one-way ANOVA followed by Bonferroni's multiple comparison test or unpaired $t$-test with Welch's correction, using GraphPad Prism v5.00 (GraphPad Software, San Diego, CA, USA). Statistically significant differences were considered for $P<0.05$. Experimental data are shown as mean \pm s.E.M.

\section{Declaration of interest}

The authors declare that there is no conflict of interest that could be perceived as prejudicing the impartiality of the research reported.

\section{Funding}

This work was supported by Foundation for Science and Technology (FCT; Grant numbers SFRH/BD/30173/2006 and SFRH/BD/60945/2009), Plurianual Program of FCT, and Program Ciência 2008.

\section{Acknowledgements}

The authors thank Catarina Ferreira for technical assistance in tissue processing for histological analysis. 


\section{References}

Almeida SA, Teofilo JM, Anselmo Franci JA, Brentegani LG \& LamanoCarvalho TL 2000 Antireproductive effect of the calcium channel blocker amlodipine in male rats. Experimental and Toxicologic Pathology 52 353-356.

Andersen CL, Jensen JL \& Orntoft TF 2004 Normalization of real-time quantitative reverse transcription-PCR data: a model-based variance estimation approach to identify genes suited for normalization, applied to bladder and colon cancer data sets. Cancer Research 64 5245-5250. (doi:10.1158/0008-5472.CAN-04-0496)

Benoff S, Cooper GW, Hurley I, Mandel FS, Rosenfeld DL, Scholl GM, Gilbert BR \& Hershlag A 1994 The effect of calcium ion channel blockers on sperm fertilization potential. Fertility and Sterility 62 606-617.

Carolan JC, Fitzroy Cl, Ashton PD, Douglas AE \& Wilkinson TL 2009 The secreted salivary proteome of the pea aphid Acyrthosiphon pisum characterised by mass spectrometry. Proteomics 9 2457-2467. (doi:10. 1002/pmic.200800692)

Erkkila K, Henriksen K, Hirvonen V, Rannikko S, Salo J, Parvinen M \& Dunkel L 1997 Testosterone regulates apoptosis in adult human seminiferous tubules in vitro. Journal of Clinical Endocrinology and Metabolism 82 2314-2321. (doi:10.1210/jc.82.7.2314)

Fisher D 2002 New light shed on fluid formation in the seminiferous tubules of the rat. Journal of Physiology 542 445-452. (doi:10.1113/jphysiol. 2002.018648)

Franchi E \& Camatini M 1985 Evidence that a $\mathrm{Ca}^{2+}$ chelator and a calmodulin blocker interfere with the structure of inter-Sertoli junctions. Tissue \& Cell 17 13-25. (doi:10.1016/0040-8166(85)90012-6)

Fujita T, Uchida K \& Maruyama N 1992 Purification of senescence marker protein-30 (SMP30) and its androgen-independent decrease with age in the rat liver. Biochimica et Biophysica Acta 1116 122-128. (doi:10.1016/ 0304-4165(92)90108-7)

Fujita T, Shirasawa T, Uchida K \& Maruyama N 1996 Gene regulation of senescence marker protein-30 (SMP30): coordinated up-regulation with tissue maturation and gradual down-regulation with aging. Mechanisms of Ageing and Development 87 219-229. (doi:10.1016/0047-6374 (96)01711-3)

Geoffroy-Siraudin C, Perrard MH, Chaspoul F, Lanteaume A, Gallice P, Durand P \& Guichaoua MR 2010 Validation of a rat seminiferous tubule culture model as a suitable system for studying toxicant impact on meiosis effect of hexavalent chromium. Toxicological Sciences 116 286-296. (doi:10.1093/toxsci/kfq099)

Giampietri C, Petrungaro S, Coluccia P, D'Alessio A, Starace D, Riccioli A, Padula F, Palombi F, Ziparo E, Filippini A et al. 2005 Germ cell apoptosis control during spermatogenesis. Contraception 72 298-302. (doi:10. 1016/j.contraception.2005.04.011)

Gilleron J, Carette D, Carpentier F, Segretain D \& Pointis G 2009 Three-dimensional analysis of connexin 43 gap junction in the ex vivo rat seminiferous tubules: short-term effects of hormonal effectors. Microscopy Research and Technique 72 845-855. (doi:10.1002/jemt. 20731)

Gorczynska E \& Handelsman DJ 1995 Androgens rapidly increase the cytosolic calcium concentration in Sertoli cells. Endocrinology 136 2052-2059. (doi:10.1210/en.136.5.2052)

Gorczynska-Fjalling E 2004 The role of calcium in signal transduction processes in Sertoli cells. Reproductive Biology 4 219-241.

Grima J, Wong CC, Zhu LJ, Zong SD \& Cheng CY 1998 Testin secreted by Sertoli cells is associated with the cell surface, and its expression correlates with the disruption of Sertoli-germ cell junctions but not the inter-Sertoli tight junction. Journal of Biological Chemistry 273 21040-21053. (doi:10.1074/jbc.273.33.21040)

Hellemans J, Mortier G, De Paepe A, Speleman F \& Vandesompele J 2007 $q B a s e$ relative quantification framework and software for management and automated analysis of real-time quantitative PCR data. Genome Biology 8 R19. (doi:10.1186/gb-2007-8-2-r19)

Inagaki S \& Yamaguchi M 2001 Regulatory role of endogenous regucalcin in the enhancement of nuclear deoxyribonuleic acid synthesis with proliferation of cloned rat hepatoma cells (H4-II-E). Journal of Cellular Biochemistry 82 704-711. (doi:10.1002/jcb.1193)

Ishigami A, Fujita T, Handa S, Shirasawa T, Koseki H, Kitamura T, Enomoto N, Sato N, Shimosawa T \& Maruyama N 2002 Senescence marker protein-30 knockout mouse liver is highly susceptible to tumor necrosis factor-alpha- and Fas-mediated apoptosis. American Journal of Pathology 161 1273-1281. (doi:10.1016/S0002-9440(10)64404-5)

Isogai M, Oishi K \& Yamaguchi M 1994a Serum release of hepatic calciumbinding protein regucalcin by liver injury with galactosamine administration in rats. Molecular and Cellular Biochemistry 136 85-90. (doi:10. 1007/BF00931609)

Isogai M, Shimokawa N \& Yamaguchi M 1994b Hepatic calcium-binding protein regucalcin in released into the serum of rats administered orally carbon tetrachloride. Molecular and Cellular Biochemistry 131 173-179. (doi:10.1007/BF00925954)

Izumi T \& Yamaguchi M 2004a Overexpression of regucalcin suppresses cell death and apoptosis in cloned rat hepatoma H4-II-E cells induced by lipopolysaccharide, PD 98059, dibucaine, or Bay K 8644. Journal of Cellular Biochemistry 93 598-608. (doi:10.1002/jcb. 20214)

Izumi T \& Yamaguchi M 2004b Overexpression of regucalcin suppresses cell death in cloned rat hepatoma H4-II-E cells induced by tumor necrosis factor-alpha or thapsigargin. Journal of Cellular Biochemistry 92 296-306. (doi:10.1002/jcb.20056)

Johnson C, Jia Y, Wang C, Lue YH, Swerdloff RS, Zhang XS, Hu ZY, Li YC, Liu YX \& Hikim AP 2008 Role of caspase 2 in apoptotic signaling in primate and murine germ cells. Biology of Reproduction 79 806-814. (doi:10.1095/biolreprod.108.068833)

Juneja R, Gupta I, Wali A, Sanyal SN, Chakravarti RN \& Majumdar S 1990 Effect of verapamil on different spermatozoal functions in guinea pigs - a preliminary study. Contraception 41 179-187. (doi:10.1016/00107824(90)90146-M)

Kaisman-Elbaz T, Sekler I, Fishman D, Karol N, Forberg M, Kahn N, Hershfinkel M \& Silverman WF 2009 Cell death induced by zinc and cadmium is mediated by clusterin in cultured mouse seminiferous tubules. Journal of Cellular Physiology 220 222-229. (doi:10.1002/jcp. 21754)

Kurota H \& Yamaguchi M 1996 Steroid hormonal regulation of calciumbinding protein regucalcin mRNA expression in the kidney cortex of rats. Molecular and Cellular Biochemistry 155 105-111. (doi:10.1007/ BF00229307)

Lee JH, Kim H, Kim DH \& Gye MC 2006 Effects of calcium channel blockers on the spermatogenesis and gene expression in peripubertal mouse testis. Archives of Andrology 52 311-318. (doi:10.1080/ 01485010600664024)

Lee JH, Ahn HJ, Lee SJ, Gye MC \& Min CK 2011 Effects of L- and T-type $\mathrm{Ca}(2+)$ channel blockers on spermatogenesis and steroidogenesis in the prepubertal mouse testis. Journal of Assisted Reproduction and Genetics 28 23-30. (doi:10.1007/s10815-010-9480-x)

Lv S, Wei L, Wang JH, Wang JY \& Liu F 2007 Identification of novel molecular candidates for acute liver failure in plasma of BALB/c murine model. Journal of Proteome Research 6 2746-2752. (doi:10.1021/ pr0701759)

Lv S, Wang JH, Liu F, Gao Y, Fei R, Du SC \& Wei L 2008 Senescence marker protein 30 in acute liver failure: validation of a mass spectrometry proteomics assay. BMC Gastroenterology 8 17. (doi:10.1186/1471230X-8-17)

Maia CJ, Santos CR, Schmitt F \& Socorro S 2008 Regucalcin is expressed in rat mammary gland and prostate and down-regulated by 17 betaestradiol. Molecular and Cellular Biochemistry 311 81-86. (doi:10. 1007/s11010-007-9697-x)

Maia C, Santos C, Schmitt F \& Socorro S 2009 Regucalcin is underexpressed in human breast and prostate cancers: effect of sex steroid hormones. Journal of Cellular Biochemistry 107 667-676. (doi:10.1002/ jcb.22158)

Manna PR, Pakarinen P, El-Hefnawy T \& Huhtaniemi IT 1999 Functional assessment of the calcium messenger system in cultured mouse Leydig tumor cells: regulation of human chorionic gonadotropin-induced expression of the steroidogenic acute regulatory protein. Endocrinology 140 1739-1751. (doi:10.1210/en.140.4.1739)

Matsuyama S, Kitamura T, Enomoto N, Fujita T, Ishigami A, Handa S, Maruyama N, Zheng D, Ikejima K, Takei Y et al. 2004 Senescence marker protein-30 regulates Akt activity and contributes to cell survival in Hep G2 cells. Biochemical and Biophysical Research Communications 321 386-390. (doi:10.1016/j.bbrc.2004.06.161) 
Meachem SJ, Schlatt S, Ruwanpura SM \& Stanton PG 2007 The effect of testosterone, dihydrotestosterone and oestradiol on the re-initiation of spermatogenesis in the adult photoinhibited Djungarian hamster. Journal of Endocrinology 192 553-561. (doi:10.1677/JOE-06-0136)

Montano LM, Calixto E, Figueroa A, Flores-Soto E, Carbajal V \& Perusquia M 2008 Relaxation of androgens on rat thoracic aorta: testosterone concentration dependent agonist/antagonist L-type $\mathrm{Ca}^{2+}$ channel activity, and 5beta-dihydrotestosterone restricted to L-type $\mathrm{Ca}^{2+}$ channel blockade. Endocrinology 149 2517-2526. (doi:10.1210/en. 2007-1288)

Nakajima M, Murata T \& Yamaguchi M 1999 Expression of calciumbinding protein regucalcin mRNA in the cloned rat hepatoma cells $(\mathrm{H} 4-$ II-E) is stimulated through $\mathrm{Ca}^{2+}$ signaling factors: involvement of protein kinase C. Molecular and Cellular Biochemistry 198 101-107. (doi:10. 1023/A:1006996506238)

Nandi S, Banerjee PP \& Zirkin BR 1999 Germ cell apoptosis in the testes of Sprague-Dawley rats following testosterone withdrawal by ethane 1,2dimethanesulfonate administration: relationship to Fas? Biology of Reproduction 61 70-75. (doi:10.1095/biolreprod61.1.70)

Oliveira PF, Sousa M, Barros A, Moura T \& Rebelo da Costa A 2009a Membrane transporters and cytoplasmatic $\mathrm{pH}$ regulation on bovine Sertoli cells. Journal of Membrane Biology 227 49-55. (doi:10.1007/ s00232-008-9139-z)

Oliveira PF, Sousa M, Barros A, Moura T \& Rebelo da Costa A 2009b Intracellular $\mathrm{pH}$ regulation in human Sertoli cells: role of membrane transporters. Reproduction 137 353-359. (doi:10.1530/REP-08-0363)

Oliver VL, Anderson C, Ventura S \& Haynes JM 2010 Androgens regulate adenylate cyclase activity and intracellular calcium in stromal cells derived from human prostate. Prostate 70 1222-1232. (doi:10.1002/ pros.21157)

Omura M \& Yamaguchi M 1999 Effect of anti-regucalcin antibody on neutral phosphatase activity in rat liver cytosol: involvement of endogenous regucalcin. Molecular and Cellular Biochemistry 197 25-29. (doi:10.1023/A:1006979606225)

O'Shaughnessy PJ, Verhoeven G, De Gendt K, Monteiro A \& Abel MH 2010 Direct action through the Sertoli cells is essential for androgen stimulation of spermatogenesis. Endocrinology 151 2343-2348. (doi:10. 1210/en.2009-1333)

Otomo Y \& Yamaguchi M 2006 Regulatory effect of exogenous regucalcin on cell function in osteoblastic MC3T3-E1 cells: involvement of intracellular signaling factor. International Journal of Molecular Medicine 18 321-327.

Pandey AK, Li W, Yin X, Stocco DM, Grammas P \& Wang X 2010 Blocking L-type calcium channels reduced the threshold of cAMP-induced steroidogenic acute regulatory gene expression in MA-10 mouse Leydig cells. Journal of Endocrinology 204 67-74. (doi:10.1677/JOE-09-0206)

Pentikainen V, Erkkila K, Suomalainen L, Parvinen M \& Dunkel L 2000 Estradiol acts as a germ cell survival factor in the human testis in vitro. Journal of Clinical Endocrinology and Metabolism 85 2057-2067. (doi:10.1210/jc.85.5.2057)

Popova NY, Dukhanin AS \& Shimanovskii NL 2007 Nongenomic effect of androgens on $\mathrm{Ca}(2+)$ concentration in human lymphocytes. Bulletin of Experimental Biology and Medicine 143 605-607. (doi:10.1007/ s10517-007-0193-9)

Print CG \& Loveland KL 2000 Germ cell suicide: new insights into apoptosis during spermatogenesis. BioEssays 22 423-430. (doi:10.1002/ (SICI)1521-1878(200005)22:5<423::AID-BIES4 > 3.0.CO;2-0)

Shimokawa N \& Yamaguchi M 1992 Calcium administration stimulates the expression of calcium-binding protein regucalcin mRNA in rat liver. FEBS Letters 305 151-154. (doi:10.1016/0014-5793(92)80884-J)
Shimokawa N \& Yamaguchi M 1993 Expression of hepatic calcium-binding protein regucalcin mRNA is mediated through $\mathrm{Ca}^{2+} /$ calmodulin in rat liver. FEBS Letters 316 79-84. (doi:10.1016/0014-5793(93)81740-Q)

Singh J, O'Neill C \& Handelsman DJ 1995 Induction of spermatogenesis by androgens in gonadotropin-deficient (hpg) mice. Endocrinology 136 5311-5321. (doi:10.1210/en.136.12.5311)

Sousa M, Cremades N, Silva J, Oliveira C, Ferraz L, Teixeira da Silva J, Viana P \& Barros A 2002a Predictive value of testicular histology in secretory azoospermic subgroups and clinical outcome after microinjection of fresh and frozen-thawed sperm and spermatids. Human Reproduction 17 1800-1810. (doi:10.1093/humrep/17.7.1800)

Sousa M, Cremades N, Alves C, Silva J \& Barros A $2002 b$ Developmental potential of human spermatogenic cells co-cultured with Sertoli cells. Human Reproduction 17 161-172. (doi:10.1093/humrep/17.1.161)

Tesarik J, Martinez F, Rienzi L, lacobelli M, Ubaldi F, Mendoza C \& Greco E 2002 In-vitro effects of FSH and testosterone withdrawal on caspase activation and DNA fragmentation in different cell types of human seminiferous epithelium. Human Reproduction 17 1811-1819. (doi:10. 1093/humrep/17.7.1811)

Tsurusaki Y \& Yamaguchi M 2004 Role of regucalcin in liver nuclear function: binding of regucalcin to nuclear protein or DNA and modulation of tumor-related gene expression. International Journal of Molecular Medicine 14 277-281.

Turner TT, Jones CE, Howards SS, Ewing LL, Zegeye B \& Gunsalus GL 1984 On the androgen microenvironment of maturing spermatozoa. Endocrinology 115 1925-1932. (doi:10.1210/endo-115-5-1925)

Vandesompele J, De Preter K, Pattyn F, Poppe B, Van Roy N, De Paepe A \& Speleman F 2002 Accurate normalization of real-time quantitative RT-PCR data by geometric averaging of multiple internal control genes. Genome Biology 3 RESEARCH0034. (doi:10.1186/gb-2002-3-7research0034)

Vera Y, Erkkila K, Wang C, Nunez C, Kyttanen S, Lue Y, Dunkel L, Swerdloff RS \& Sinha Hikim AP 2006 Involvement of p38 mitogenactivated protein kinase and inducible nitric oxide synthase in apoptotic signaling of murine and human male germ cells after hormone deprivation. Molecular Endocrinology 20 1597-1609. (doi:10.1210/ me.2005-0395)

Yamaguchi M 2005 Role of regucalcin in maintaining cell homeostasis and function (review). International Journal of Molecular Medicine $\mathbf{1 5}$ 371-389.

Yamaguchi M \& Kurota H 1995 Expression of calcium-binding protein regucalcin mRNA in the kidney cortex of rats: the stimulation by calcium administration. Molecular and Cellular Biochemistry 146 71-77. (doi:10.1007/BF00926884)

Yamaguchi M \& Oishi K 199517 beta-Estradiol stimulates the expression of hepatic calcium-binding protein regucalcin mRNA in rats. Molecular and Cellular Biochemistry 143 137-141. (doi:10.1007/BF01816947)

Yamaguchi M \& Yamamoto T 1978 Purification of calcium binding substance from soluble fraction of normal rat liver. Chemical \& Pharmaceutical Bulletin 26 1915-1918.

Yamaguchi M, Otomo Y, Uchiyama S \& Nakagawa T 2008 Hormonal regulation of regucalcin mRNA expression in osteoblastic MC3T3-E1 cells. International Journal of Molecular Medicine 21 771-775.

Received 20 March 2011

First decision 18 April 2011

Revised manuscript received 8 June 2011

Accepted 16 June 2011 